\title{
CHANGES IN ELECTROENCEPHALOGRAM (EEG) POWER DURING SUBDOMINANT (LEFT) HAND FINGER MOVEMENTS IN FEMALES WITH DIFFERENT ALPHA RHYTHM CHARACTERISTICS
}

\section{ZMIANY MOCY ELEKTROENCEFALOGRAMU W TRAKCIE WYKONYWANIA RUCHÓW PALCAMI MNIEJ DOMINUJĄCEJ (LEWEJ) RĘKI U KOBIET Z RÓŻNYMI ZMIENNYMI RYTMU ALFA}

\author{
Alevtyna Morenko ${ }^{1(\mathrm{~A}, \mathrm{~B}, \mathrm{D})}$, Olena Morenko ${ }^{2(\mathrm{C}, \mathrm{F})}$, Olena Dmytrotsa ${ }^{1(\mathrm{~F})}$, Andriy Poruchynsky $^{1(\mathrm{D})}$, \\ Olha Korzhyk ${ }^{1(B, F)}$
}

\author{
${ }^{1}$ Faculty of Medicine and Biology, Lesya Ukrainka Eastern European \\ National University, Lutsk, Ukraine \\ ${ }^{2}$ Faculty of Medicine, Charles University, Prague, the Czech Republic
}

Authors' contribution Wkład autorów: A. Study design/planning zaplanowanie badań B. Data collection/entry zebranie danych C. Data analysis/statistics dane - analiza i statystyki D. Data interpretation interpretacja danych E. Preparation of manuscript przygotowanie artykułu F. Literature analysis/search wyszukiwanie $\mathrm{i}$ analiza literatury G. Funds collection zebranie funduszy

\section{Summary}

Background. This study investigates the indicators of electroencephalographic (EEG) oscillatory activity and processes that are correlated with manual movements executed by the subdominant (left) hand in women with a high or a low individual $\alpha$-frequency.

Material and methods. 113 healthy right-handed women from the ages of 19 to 21 were divided randomly into two experimental groups with high $(\mathrm{n}=59, \mathrm{I} \alpha \mathrm{F}>10.25 \mathrm{~Hz})$ and low $(\mathrm{n}=$ $54, \mathrm{I} \alpha \mathrm{F} \leq 10.25 \mathrm{~Hz}$ ) individual EEG $\alpha$-frequency ( $\alpha \mathrm{F})$. EEG power during flexion or extension of the subdominant hand fingers was evaluated.

Results. Manual movements performed by women, especially those exhibiting high modal $\alpha$-frequency, were accompanied by reduced $\alpha$ and $\beta$ power in mid and posterior cortical areas. These changes occurred in combination with a local power increase in $\alpha 1$-oscillations in the frontal leads. A local increase of $\alpha 3$-activity in the frontal cortex areas was also revealed in women with low I $\alpha$ F. In this same group of women, generalized increases in EEG power of $\theta$-, $\beta$ - and $\gamma$-oscillations were observed in the cortex.

Conclusions. These results revealed a greater redundancy of brain processes in women with low I $\alpha$ F power compared to women with high $\alpha$-frequency.

Keywords: brain, motor activity, attention, alpha rhythm

\section{Streszczenie}

Wprowadzenie. Niniejsza praca poświęcona jest badaniu wskaźników elektroencefalograficznej aktywności oscylacyjnej i procesów, które są skorelowane z ruchami manualnymi, u kobiet $\mathrm{z}$ wysoką lub niską indywidualną częstotliwością $\alpha$ określoną podczas ruchów manualnych wykony wanych przez mniej dominującą (lewą) rękę.

Materiał i metody. 113 zdrowych praworęcznych kobiet w wieku od 19 do 21 lat zostało podzielonych na dwie grupy eksperymentalne z wysoką $(n=59, I \alpha F \geq 10,254 \mathrm{~Hz})$ i niską $(\mathrm{n}=54$, $\mathrm{I} \alpha \mathrm{F} \leq 10,25 \mathrm{~Hz}$ ) indywidualną wartością częstotliwości EEG $\alpha(\mathrm{I} \alpha \mathrm{F})$. U tych kobiet oceniona została aktywność EEG podczas zginania lub prostowania mniej dominujących palców.

Wyniki. Ruchom manualnym wykonywanym przez kobiety, zwłaszcza o wysokiej modalnej częstotliwości $\alpha$, towarzyszyło pewne zmniejszenie mocy fal EEG $\alpha$ i $\beta$ w środkowych i tylnych obszarach kory mózgowej. Takie zmiany połączono z lokalnym wzrostem mocy w oscylacjach $\alpha 1 \mathrm{w}$ przednich przewodach. Lokalny wzrost aktywności $\alpha 3 \mathrm{w}$ obszarach kory czołowej został również ujawniony u kobiet z niską wartością I $\alpha$ F. Pewne uogólnione zwiększenie mocy fal EEG oscylacji $\theta, \beta$ i $\gamma$ zaobserwowano w korze kobiet należących do tej grupy.

Wnioski. Wyniki ujawniają większą nadmiarowość procesów mózgowych u kobiet z małą mocą fal I $\alpha \mathrm{F}$ w porównaniu z kobietami z wysoką częstotliwością $\alpha$.

Słowa kluczowe: mózg, aktywność motoryczna, uwaga, rytm alfa
Figures: 3

References: 30

Submitted: 2019 Sep 21

Accepted: 2020 Feb 10

Morenko A, Morenko 0, Dmytrotsa 0, Poruchynsky A, Korzhyk O. Changes in electroencephalogram (EEG) power during subdominant (left) hand finger movements in females with different alpha rhythm characteristics. Health Prob Civil. 2020; 14(1): 63-69.

https://doi.org/10.5114/hpc.2020.93295

Address for correspondence / Adres korespondencyjny: Alevtyna Morenko, Faculty of Medicine and Biology, Lesya Ukrainka Eastern European National University, Voli Avenue 13, 43025 Lutsk, Ukraine, e-mail: alevmore@gmail.com, phone: +38 (0332) 249327

ORCID: Alevtyna Morenko https://orcid.org/0000-0002-8585-822X, Olena Morenko https://orcid.org/0000-0002-7524-6828,

ORCID: Alevtyna Morenko https://orcid.org/0000-0002-8585-822X, Olena Morenko https://orcid.org/0000-0002-7524-6828

Olha Korzhyk https://orcid.org/0000-0002-2526-8877

Copyright: (C) Pope John Paul II State School of Higher Education in Biała Podlaska, Alevtyna Morenko, Olena Morenko, Olena Dmytrotsa, Andriy Poruchynsky, Olha Korzhyk. This is an Open Access journal, all articles are distributed under the terms of the Creative Commons Attribution-NonCommercial-ShareAlike 4.0 International (CC BY-NC-SA 4.0) License (http://creativecommons.org/licenses/by-nc-sa/4.0/), allowing third parties to copy and redistribute the material in any medium or format and to remix, transform, and build upon the material, provided the original work is properly cited and states its license. 


\section{Introduction}

Movements carried out by any of the upper limbs (manual movements, MM) are the basis of the manipulator motor activities primarily used in human daily life, education and work. The qualitative characteristics of their realization become critical in the context of the enrichment and congestion of the human information environment and the total computerization that is taking place today. Therefore, the scientific community is increasingly interested in the individual characteristics of brain processes underlying motor programming. According to recent studies [1-6], MMs are clearly associated with significant alterations in cerebral cortex activities which program and order appropriate motor formations. However, the specific details of these cerebral processes have not been fully elucidated. It is presumed that defined brain process indicators can be correlated with MM activities.

According to some literary information [7-9] the individual amplitude-frequency characteristics of the EEG $\alpha$-rhythm, in particular the modal frequency of this rhythm, can be highly informative for determining a number of human psychophysiological functions. Individuals with different $\alpha$-rhythm characteristics use different behavioral strategies, mechanisms of perception, and information processing [10]. Bazanova [11] found out that the most optimal coordination of the processes of motion organization correlated linearly with the power of the individual $\alpha$-activity EEG and reversely with the tension of the muscles of the forehead. Kristeva et al. [12] noted that an increment of the EEG $\alpha$-amplitude and a decrease of the integral power of the facial muscle electromyogram can be considered as an increase of the ability to self-control movement. It should be emphasized that the modal $\alpha$-frequency of EEG is often considered [13-18] as a sign that reflects important innate features of the structural organization of thalamic and cortical neurons, in particular, the features of ionic processes in these cells [19-21].

Taking into account the exceptional importance of the results obtained by various scientists, we have to note some insufficiency of such information to fully understand how the modal frequency of the EEG $\alpha$-rhythm can be related to the control of the activity of the distal muscles of the hand. Previous studies [20, 21, 23] showed the brain processes' features during execution of manual movements in men with different modal frequency of EEG alpha rhythm. According to the available results, examinees with initially high EEG $\alpha$-rhythm modal frequency had higher levels of selective attention and more local changes in electrical activity of the cerebral cortex during the regulation of MM. People with a low $\alpha$-frequency were characterized by less specific and differentiated cortical activation processes [20,21,23]. The functional differences previously identified in men during their performance of MMs by the subdominant hand [22] may reflect a generally relatively lower tone of cortical activation in men with a low $\mathrm{I} \alpha \mathrm{F}$ that can be specifically compensated for by increased "intensity" and an observed redundancy of brain processes. Despite the significant achievements made in this field, the literature remains sparse regarding the features of brain processes in women during MMs executed with the help of the subdominant hand.

The purpose of this study is to assess spectral-frequencies of electrical activity in the cerebral cortex during subdominant (left) hand movements performed by women with different characteristics of alpha-activity. This will contribute to the currently sparse data on objective indicators of brain activity directly associated with programming of female MM.

\section{Material and methods}

\section{Participants}

136 female volunteers from the ages of 19 to 21 participated in our study. Every examinee gave written consent. Biomedical ethics rules in accordance with the Helsinki Declaration of the World Medical Association on the Ethical Principles of Scientific and Medical Research involving Human Subjects were followed. In keeping with the medical advisory conclusions every examinee was healthy and had normal hearing.

\section{Procedure}

\section{Psychophysiological examination}

The nature of responses in the survey and execution of the motor and psychoacoustic tests were determined. The individual profiles of the manual motor asymmetry as well as auditory asymmetry were counted for each woman (K skew) (Formula 1) [20-24]. 


\section{Formula 1.}

$$
\mathrm{K}_{\text {skew }}=\frac{\Sigma_{\text {right }}-\Sigma_{\text {left }}}{\Sigma_{\text {right }}+\Sigma_{\text {left }}} \times 100 \% \text {, }
$$

where

$\Sigma_{\text {right }}$ - the number of tasks where the right hand (right ear) is dominating during their execution,

$\Sigma_{\text {left }}$ - the number of tasks under which the left hand (left ear) is dominant.

Further studies involved dextral examinees whose coefficients of manual and auditory asymmetries were positive and were above $50 \%[21,22]$. There was a total of 113 female subjects.

All examinations were performed in the morning. The profile of the asymmetry was evaluated 30 minutes before the EEG recording registration. This prevented it from influencing the experiment, particularly, the EEG results $[21,22]$.

\section{EEG testing procedures}

The examinees were in a quiescent state with their eyes closed and in a reclining position with their limbs relaxed and not crossed during the EEG testing [22]. The experiment was carried out in a room which was sound-proof and light-proof. The entire experimental procedure consistently included the following steps for each examinee:

Step 1. An EEG recording for functional balance (background);

Step 2. An EEG recording while performing the finger movements of the left (subdominant) hand.

Each step lasted $40 \mathrm{~s}$. To exclude edge effects, the EEG recording registration was initiated $15 \mathrm{~s}$ after the beginning and stopped $5 \mathrm{~s}$ before its completion [22, 23].

All instructions were reported to the examinees before the test. Finger movements were consisted of flexion or extension. Each finger was flexed or extended by the examinees in response to a sound [20-23]. The electronic version of the drum battle (Finale 2006 software) was used for this purpose. Binaural stimuli were produced by four speakers placed in different corners of the room at a distance of $1.2 \mathrm{~m}$ from the examinee's right or left ear. The stimulus duration was $130 \mathrm{~ms}$; the playback sound volume did not exceed 55-60 dB at the speakers, measured by a sound level meter (DE-3301, DER EE, Taiwan; certificate \# 025-2009, valid until 21.12.2014). Additionally, the sound level was individually regulated for each examinee to achieve functionally necessary volumes. The rate of the sound stimuli delivery was $2 \mathrm{~Hz}$.

\section{Registration and primary analysis of EEG data}

Active electrodes were placed in accordance with the International 10-20 system at nineteen points on the scalp during the monopolar EEG (Neurocom EEG System, Xai-Medica, Ukraine; Certificate \# 6038/2007, valid until 18.04.2014) recording, using ear electrodes as a reference. The Fourier analysis era was $4 \mathrm{~s}$ with a $50 \%$ overlap. Duration of sample was $40 \mathrm{~s}$. ICA-procedure analysis was used for the rejection of EEG anomalies [20-23].

The power $\left(\mu \mathrm{V}^{2}\right)$ of brain electrical activity in the $\theta-, \alpha-, \beta$ - and $\gamma$-frequency intervals were also evaluated. Taking into consideration the functional heterogeneity of different sub-bands of the EEG $\alpha$ - and $\beta$-rhythms, the changes in power for each were considered [23].

The maximum frequency peak of the $\alpha$-rhythm was determined for each woman in each EEG lead at a functional balance [24]. Its value was averaged for all leads and the values were considered to be the examinee's individual $\alpha$-frequency (the individual alpha-frequency of EEG, I $\alpha \mathrm{F}$ and $\mathrm{Hz}$ ). The I $\alpha \mathrm{F}$ median was also determined and calculated for the entire subject group. Thus, subjects were grouped according to individual values relative to the median - a high I $\alpha$ F group and low I $\alpha$ F group [20-23].

The EEG frequency interval limits were determined individually, relying on the value of the examinee's I $\alpha F$. The following algorithm $[20,21,22,23,25,26]$ was used and the upper limit of the $\alpha 3$-subband was set to the right side of the I $\alpha \mathrm{F}$ in increments of $2 \mathrm{~Hz}$. It corresponded to the lower limit of the $\beta 1$-band. The upper limit of the $\beta 1$-subband was defined according to standard concepts as $25 \mathrm{~Hz}$. The lower limit of the $\alpha 2$-band was determined in steps of $2 \mathrm{~Hz}$ to the left of the peak and the $\alpha 1$-band in $4-\mathrm{Hz}$ steps, as well as $\theta$-frequencies in $6 \mathrm{~Hz}$ steps. Limits of $\beta 2$ - and $\gamma$-bands were recognized as is standard, specifically, 26-35 $\mathrm{Hz}$ and 36-45 Hz [21, 22,23, $25,26]$. 
The resulting individual values of the power of EEG oscillations within the selected groups of women were averaged for each lead.

\section{Statistical analyses}

A statistical data analysis was performed by using the Statistica 6.0 software package (Stat-Soft, 2001). Any normalcy of the data distribution in the examinees' groups was evaluated by the Shapiro-Wilk test (indicator SW). Test results showed that all of the study's samples had a normal data distribution [20-23]. To estimate the significance of differences existing in the examinees' groups, the Student's t-test (index t) was used to assess for differences between testing steps both for independent equal samples and for dependent samples. Significant differences between female groups and between testing steps were considered statistically significant at $\mathrm{p} \leq$ 0.05 and $\mathrm{p} \leq 0.01$.

\section{Results and Discussion}

The individual modal frequency evaluation of the $\alpha$-EEG activity and individual limits of the frequency content of the EEG sub-range in female examinees

The average value of the modal frequency of any $\alpha$-activity in samples of female examinees was $10.25 \pm 0.03$ $\mathrm{Hz}$ (Figure 1) [21]. Since the individual $\alpha$-frequency value histogram in the female examinees differed from a normal distribution we calculated the conditional distribution of samples under the average mean of the modal frequency of $\alpha$-activity. We formed two groups - a group with high values for $\operatorname{I} \alpha \mathrm{F}(\mathrm{n}=59, \mathrm{I} \alpha \mathrm{F} \geq 10.25 \mathrm{~Hz})$ and a group with low values for $\mathrm{I} \alpha \mathrm{F}(\mathrm{n}=54, \mathrm{I} \alpha \mathrm{F}<10.25 \mathrm{~Hz})$.

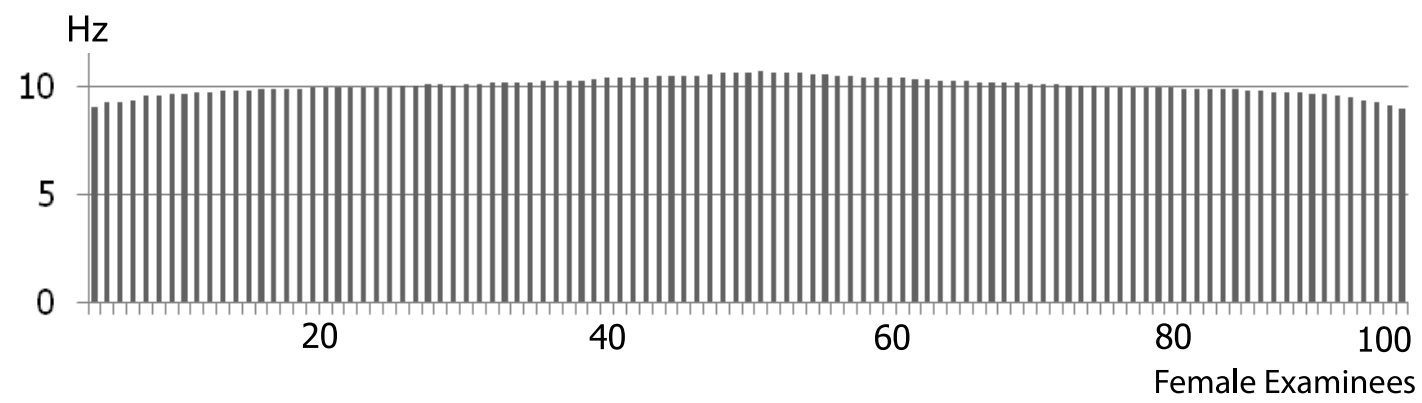

Figure 1. Histogram of $\alpha$-frequency mode in female examinees

Note: Vertical columns represent individual values of the EEG $\alpha$-frequency mode in samples of female examinees.

Indicators of EEG power during manual movements of the subdominant hand in women with different $\alpha$-rhythm modal frequency

Women with high I $\alpha$ F showed a power increase for EEG $\alpha 1-\theta$-oscillations in the frontal areas (p $\leq 0.01)$. According to results from Klimesh [25], Watson and Buzsáki [27] and Avery et al. [28], such changes may reflect priming in human memory, allowing for maintenance of focus on sensory and motor information as well as higher selective attention. Intense $\gamma$-activity under these conditions was found in the ventralis frontal $(p \leq 0.05)$ and parietal-occipital areas ( $\mathrm{p} \leq 0.01)$, while $\beta$-activity was only found in the ventralis frontal areas (Figure 2 ). 


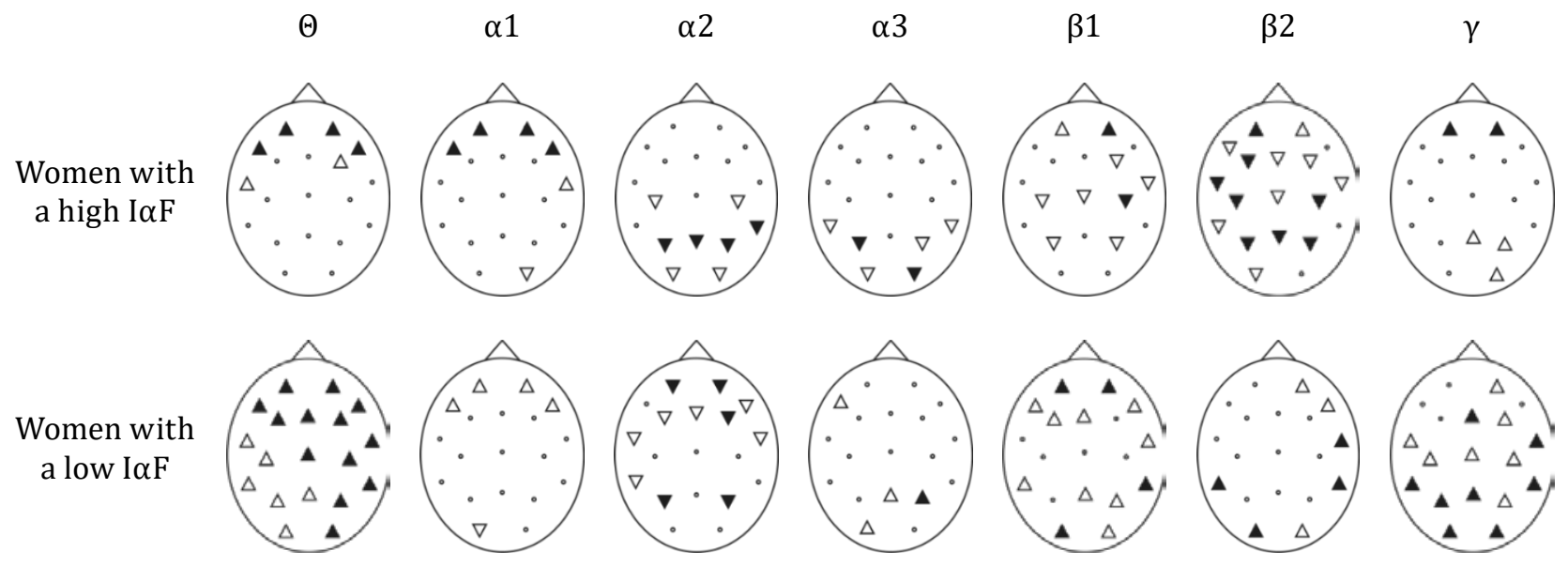

Figure 2. Topo maps of changes in EEG power fluctuations through the execution of manual movements by female groups Note:

$\triangle \boldsymbol{\Delta} / \nabla \boldsymbol{\nabla}$ - increase (triangle up) /decrease (triangle down) in EEG power fluctuations through the execution of manual movements compared to power in a quiescent state, $\mathrm{p} \leq 0.05$ (white triangle), $\mathrm{p} \leq 0.01$ (black triangle).

Such a local synchronization characteristics of $\gamma$-activity in the cortex are considered by Watson and Buzsáki [27] to be criterion for efficiency in cortical interactions of the neural detector networks encoding any sensory information. However, decreased power of EEG $\alpha$ - and $\beta$-waves defined by our data, particularly in the posterior cortical areas (with $\mathrm{p} \leq 0.05$ to $\mathrm{p} \leq 0.01$ ), may prove that some activity increased in cortical areas as previously investigated by Klimesh [25], Watson and Buzsáki [27] and Tebenova [29]. Identification of activation processes in cortical structures may reveal their direct participation in the processes of sensory analysis, motor programming and integration of sensory and motor information.

Higher power rates of $\alpha 1$-oscillations in the frontal areas $(\mathrm{p} \leq 0.05)$ were particular to women with low $\mathrm{I} \alpha \mathrm{F}$. The observation of increasing capacity measures for $\theta-, \alpha 3-, \beta$ - and $\gamma$-waves were more generalized (with $\mathrm{p} \leq 0.05$ to $\mathrm{p} \leq 0.01$ ) (Figure 2). Typical power increases of $\alpha 3$-waves in the frontal area $(\mathrm{r} \leq 0.05)$ found in women with a low $\mathrm{I} \alpha \mathrm{F}$ is suggestive of an additional selective inhibition mechanism of the sensory input [1, 30] during motor programming. From a functional point of view, these results allow for the elucidation of a pattern - an EEG-correlate of the process comparing the afferent information flows with the new parameters from muscle activities, characterized by the top-down effects of the frontal cortex, with the previous motor program. According to Ioffe [1], in the course of MMs performed with the subdominant hand, such descending inhibitory influences generally prevent motor programming. Kostandov et al. [30] reported they may indicate that processes of plasticity reduced motor programming in our experiment if they were performed by women with low I $\alpha$ F, particularly with their unresponsive hand, and a need to observe the specified tempo. Some $\beta$ - and $\gamma$-activity intensively increased in the cortex was nonspecific.

Women with low I $\alpha$ F particularly showed a decrease in power rates for cortical EEG $\alpha 1$ - and $\alpha 2$-frequency oscillations contrary to such changes in the electrogenesis. These $\alpha 1$-activity changes occurred locally in the right occipital lobe $(\mathrm{p} \leq 0.05)$ and $\alpha 2$-fluctuations were more common in the cortex (with $\mathrm{p} \leq 0.05$ to $\mathrm{p} \leq 0.01$ ). Similar to cases in women with high $\mathrm{I} \alpha \mathrm{F}$, this pattern may be associated with the activation of the cortical areas involved in the analysis of sensory-motor information [25, 27, 29].

\section{Intergroup differences}

Any execution of MM by means of the subdominant (left) hand was accompanied by higher EEG power in the cerebral cortex of women with low I $\alpha \mathrm{F}$ versus women with high $\alpha$-frequency ( $\mathrm{p} \leq 0.05$ to $\mathrm{p} \leq 0.01$ ) (Figure 3). According to Kostandov et al. [30] such differences may indicate a predominance of non-specific cortical activities. 


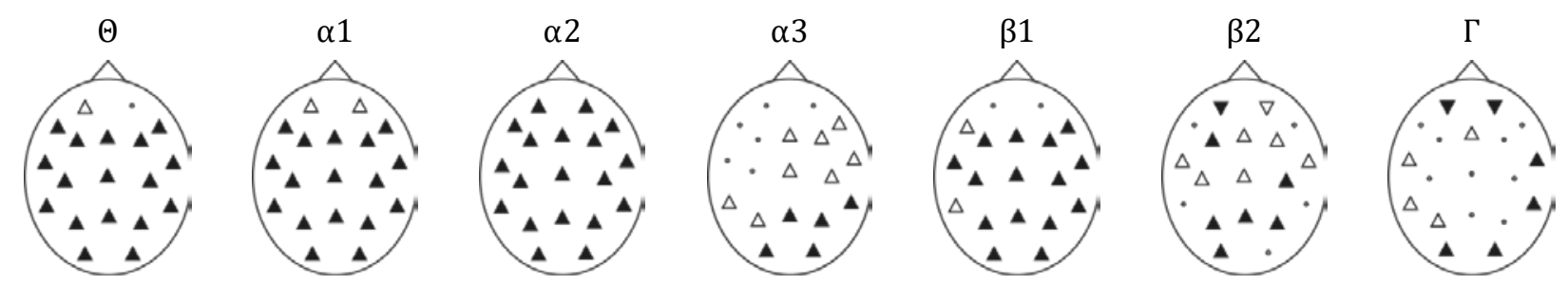

Figure 3. Intergroup differences in EEG power fluctuations through the execution of manual movements Note:

$\triangle \boldsymbol{\Delta} / \nabla \boldsymbol{\nabla}$ higher/lower power in women with a low I $\alpha \mathrm{F}$ in comparison with women with a high I $\alpha \mathrm{F}, \mathrm{p} \leq 0.05$ (white triangle), $\mathrm{p} \leq 0.001$ (black triangle).

\section{Conclusions}

The subdominant hand finger flexions and extensions in response to sensory signals, especially performed in women with high modal $\alpha$-frequency, were accompanied with an electrogenesis power reduction in the cortical areas responsible for sensory analysis, motor programming and integration of sensory and motor information. Such changes were combined with a local power increase of $\alpha 1$-oscillations in the frontal leads, primarily due to the strengthening of selective attention and memory processes. Women with low I $\alpha \mathrm{F}$ were characterized by an increase in local $\alpha 3$-activity in the frontal areas of the cortex, which may reflect additional inhibition of sensory input during the motor programming. The increase of power generally observed in the EEG $\theta$ - and $\beta$-oscillations in the cortex of women with low $\mathrm{I} \alpha \mathrm{F}$ provides clear evidence of the role of non-specific mechanisms of activation. Women with low I $\alpha$ F power had higher EEG frequency components and a relatively greater redundancy of brain processes compared to the group of women with high $\alpha$-frequency.

\section{Disclosures and acknowledgements}

This work was performed as a research project funded with the state budget funds of Ukraine, reg. no. $0111 \mathrm{U} 002143$.

\section{References:}

1. Ioffe ME, Chernikova LA, Umarova RM, Katsuba NA, Kulikov MA. Learning postural tasks in hemiparetic patients with lesions of left versus right hemisphere. Experimental Brain Research. 2010; 201(4): 753-761. https://doi.org/10.1007/s00221-009-2091-z

2. Ruge D, Muggleton N, Hoad D, Caronni A, Rothwell JC. An unavoidable modulation? Sensory attention and human primary motor cortex excitability. Europ J of Neurosci. 2014; 40(5): 2850-2858. https://doi.org/10.1111/ejn.12651

3. Caminiti R, Borra E, Visco-Comandini F, Battaglia-Mayer A, Averbeck BB, Luppino G. Computational architecture of the parieto-frontal network underlying cognitive-motor control in monkeys. ENEURO. 2017; 4(1): 1-35. https://doi.org/10.1523/ENEUR0.0306-16.2017

4. Cisek P. Neural representations of motor plans, desired trajectories, and controlled object. Cognitive Processing. 2005; 6(1): 15-24. https://doi.org/10.1007/s10339-004-0046-7

5. Kim HF, Hikosaka O. Parallel basal ganglia circuits for voluntary and automatic behaviour to reach rewards. Brain. 2015; 138(7): 1776-1800. https://doi.org/10.1093/brain/awv134

6. Müller GR, Neuper C, Rupp R, Keinrath C, Gerner HJ, Pfurtscheller G. Event-related beta EEG changes during wrist movements induced by functional electrical stimulation of forearm muscles in man. Neurosci Letters. 2003; 340(2): 143-147. https://doi.org/10.1016/S0304-3940(03)00019-3

7. Kaplan AJ, Borisov SV, Zheligovskiy VA. [Classification of the adolescent EEG by the spectral and segmental characteristics for normals]. J I.P. Pavlov Journal of Higher Nervous Activity. 2005; 55(4): $478-486$ (in Russian).

8. Razumnikova OM, Yashanina AA. Roles of rational and irrational cognitive styles in the reactivity of the $\alpha$ rhythm in convergent and divergent thinking. Neuroscience and Behavioral Physiology. 2018; 48(7): 835-841. https://doi.org/10.1007/s11055-018-0637-x

9. Umryukhin EA, Dzhebrailova TD, Korobeinikova II, Karatygin NA. [Physiological correlates of individual differences in decision-making time during purposeful mental activity in humans]. Human Physiology. 2008; 34(5): 574-580 (in Russian). https://doi.org/10.1134/S0362119708050058 
10. Bogdanov M, Timmermann JE, Gläscher J, Hummel FC, Schwabe L. Causal role of the inferolateral prefrontal cortex in balancing goal-directed and habitual control of behavior. Scientific Reports. 2018; 8(1): 9382. https://doi.org/10.1038/s41598-018-27678-6

11. Bazanova OM. Role of individual posterior dominant alpha rhythm frequency EEG in psychophysiological individual differences. International Journal of Psychophysiology. 2014; 94(2): 177-177. https://doi.org/10.1016/j.ijpsycho.2014.08.754

12. Kristeva R, Chakarov V, Losch F, Hummel S, Popa T, Schulte-Mönting J. Electroencephalographic spectral power in writer's cramp patients: evidence for motor cortex malfunctioning during the cramp. NeuroImage. 2005; 27(3): 706-714. https://doi.org/10.1016/j.neuroimage.2005.05.004

13. Anderson MP, Mochizuki T, Xie J, Fischler W, Manger JP, Talley EM, et al. Thalamic Ca 3.1 T-type Ca ${ }^{2+}$ channel plays a crucial role in stabilizing sleep. Proceedings of the National Academy of Sciences of the USA. 2005; 102(5): 1743-1748. https://doi.org/10.1073/pnas.0409644102

14. Page AJ, O’Donnell TA, Blackshaw LA. Inhibition of mechanosensitivity in visceral primary afferents by GABA(B) receptors involves calcium and potassium channels. Neuroscience. 2006; 137(2): 627-636. https://doi.org/10.1016/j.neuroscience.2005.09.016

15. Spergel DJ. Calcium and small-conductance calcium-activated potassium channels in gonadotropinreleasing hormone neurons before, during, and after puberty. J of Endocrinology. 2007; 148(5): 2383-2390. https://doi.org/10.1210/en.2006-1693

16. Anokhin A, Muller V, Lindenberger U, Heath AC, Myers E. Genetic influences on dynamic complexity of brain oscillations. Neuroscience Letter. 2006; 397(1-2): 93-98. https://doi.org/10.1016/j.neulet.2005.12.025

17. Smit CM, Wright MJ, Hansell NK, Geffen GM, Martin NG. Genetic variation of individual alpha frequency $(\mathrm{I} \alpha \mathrm{F})$ and alpha power in a large adolescent twin sample. Int J of Psychophysiol. 2006; 61(2): 235-243. https://doi.org/10.1016/j.ijpsycho.2005.10.004

18. Bellone C, Nicoll RA. Rapid bidirectional switching of synaptic NMDA receptors. Neuron. 2007; 55(5): 779788. https://doi.org/10.1016/j.neuron.2007.07.035

19. Ng SC, Raveendran P. EEG peak alpha frequency as an indicator for physical fatigue. Medicon. 2007; 16: 517520. https://doi.org/10.1007/978-3-540-73044-6_132

20. Morenko AG. EEG activity during realization of manual movements by individuals with different characteristics of the alpha rhythm. Neurophysiology. 2017; 49(2): 142-150. https://doi.org/10.1007/s11062-017-9643-9

21. Korzgyk 0, Morenko A. Coherence of EEG frequency components while performing alternative finger movements in women with different modal frequency of alpha-rhythm. Scientific Bulletin of Lesya Ukrainka Volyn National University. Biological Sciences. 2015; 12(313): 112-118. https://doi.org/10.29038/26174723-2015-313-112-118

22. Korzhyk 0, Morenko O, Morenko A, Kotsan I. The electrical brain activity in men with different alpha-rhythm characteristics during manual movements executed by the subdominant hand. Annals of Neuroscienes. 2018; 25: 98-104. https://doi.org/10.1159/000487065

23. Morenko A, Morenko O. Electrical activity of the cerebral cortex during the perception of sensory signals in women with different characteristics of alpha rhythm. Annals of Neuroscienses. 2016; 23(4): $235-240$. https://doi.org/10.1159/000449484

24. Zhavoronkova L. [Right-handed people, the left-hander. Hemispheric asymmetry of the human brain biopotentials]. Krasnodur: Ekoinvest; 2009 (in Russian).

25. Klimesch W. Alpha-band oscillations, attention, and controlled access to stored information. Trends Cogn. Sci. 2012; 16(12): 606. https://doi.org/10.1016/j.tics.2012.10.007

26. Angelakis E, Lubar JF, Stathopoulou S, Kounios J. Peak alpha frequency: an electroencephalographic measure of cognitive preparedness. Clinical Neurophysiology. 2004; 115(4): 887-897. https://doi.org/10.1016/j.clinph.2003.11.034

27. Watson BO, Buzsáki GD. Sleep, memory \& brain rhythms. The Journal of the American Academy of Arts \& Sciences. 2015; 144(1): 67-82. https://doi.org/10.1162/DAED_a_00318

28. Avery MC, Dutt N, Krichmar JL. Mechanisms underlying the basal forebrain enhancement of top-down and bottom-up attention. Europ J of Neurosci. 2014; 39(5): 852-865. https://doi.org/10.1111/ejn.12433

29. Tebenova K. [The study of the brain bioelectric activity in telephone exchange operators] [Internet]. Sovremennye problemy nauki i obrazovania. 2009; 4: 138-141 [cited 2019 Jul 10]. Available from: https://www.science-education.ru/ru/article/view?id=1217 (in Russian).

30. Kostandov EA, Cheremushkin EA, Yakovenko IA, Petrenko NE. [Relationships between the flexibility of cognitive performance and the $\alpha$-rhythm response to conditioning stimuli]. Human Physiol. 2015; 41(5): 468-477 (in Russian). https://doi.org/10.1134/S0362119715050060 